\title{
The Victory of Culture Games (VOC-Games): Math-Based Learning Media 3D and Augmented Reality as A Conservation Culture
}

\author{
Binti Isti'towatul Isti'aroh \\ Nonformal Education Department \\ State University of Malang \\ Malang, Indonesia \\ tya.tef@gmail.com
}

\author{
Zainur Ridho Wahyu Ismail \\ Public Health Department \\ State University of Malang \\ Malang, Indonesia \\ lokerwahyu@gmail.com
}

\author{
Fitrah Izul Falaq \\ Technological Education Department \\ State University of Malang \\ Malang, Indonesia \\ fitrahizzulfalaq@gmail.com
}

\begin{abstract}
The victory of Culture Games (VOC-Games) develop as mathematics learning media based on $3 d$ and augmented reality as an effort to preserve Indonesian culture. The learning media was initiated to solve problems in mathematics learning. To increase the attractiveness and capability of learners, this learning media combined with 3D technology and augmented reality. It is packaged interactively through games and learning with a group system. VOC-Games connects between cyberspace learning/digital with the real life of learners. The concept is connected through questions that can be scanned by learners in the board game. The advantages of VOC-Games are (1) able to attract student learning, (2) with augmented reality, (3) train students' ability in intrapersonal and interpersonal, (4) emphasize on internalization of values, (5) easy to realize and developed massively, (6) varied content and (7) a fun learning model.
\end{abstract}

Keywords - mathematics learning media, VOC-games, 3D, augmented reality

\section{INTRODUCTION}

Learning media technology always develops in accordance with the development of information technology and the needs of learners in getting information. Several years ago, digital-based learning using Powerpoint media could already be used to present what we wanted to convey to students. Following this, digital book-based learning media (e-book) combined with web-based learning media in the form of LMS (Learning Management System), is the solution to the needs of blended learning which is still widely used by teachers/lecturers [1].

Furthermore, in line with the widespread use of gadgets/smartphones among teachers and students, learning technology then evolved towards Android mobile-based media that forced teachers to compete to develop various android-based learning applications with multimedia-based content that can be used by students to study in class or outside the classroom [2]. Not only that, android-based learning applications are now beginning to develop towards Augmented Reality (AR) technology that combines virtual and 2-dimensional or 3-dimensional objects into a 3dimensional environment and projects these virtual objects in real terms. The combination of this technology allows realtime integration between virtual content on the computer and the display directly on the video [3].

AR technology became booming when the Pokemon Go game was a while ago. A snack company also produces chokers with BoBoiBoy battle-cards that use augmented reality technology as a marketing campaign method. Utilization of augmented reality in the learning process is an effort made to correlate learning with technology that develops in the 21 st century [4].

One example of the use of Augmented Reality technology in learning is AR to study body anatomy, knowledge of the earth and space, life under the sea, and so on. Through AR-based applications, students can learn about human organs, for example the human skull in a 3dimensional form virtually and interact with these virtual objects [3]. By using AR a student can learn visually and interactively about the earth and space and various life under the sea.

Learning mathematics has a very important role in the world of education in Indonesia. This is evident in the subjects whom he turned to mathematics as a staple in every level of education, starting from elementary school up to high school [5]. This fact is reinforced with national examination (UN) which renders mathematics as one of the graduation competencies.

However, not a few opinions say that the teaching of mathematics, especially in elementary schools, yet emphasizes the development power of reason (reasoning), logic and thought process students [6]. During this time, the teaching of mathematics is more dominated by a mechanistic lecture method. The teacher becomes the student and learning resource center as a listener, mimic, and imitate what is delivered. Students are given little space to optimize potential himself, develop reasoning as well as his creativity. Not only that, learning math seems considered off to develop the personality of the student. Learning mathematics tends to slip on the cognitive factors, but the development of personality is part of the life skills that have a very important role in my life [7].

Facing the conditions, needed an alternative solution that is able to make math learning into a more humanistic, congenial, and emphasize the creativity of students. Learning that not only deals with the cognitive aspects, but rather put forward on the internalization of the values in an effort to shape the social intelligence and personality of students [1]. One of them is by functionality digital technology that is able to integrate mathematics learning culture in real life in real terms [8].

In its implementation, the media learning offer this learning method combined with cooperative learning. Through these methods, in addition to studying mathematics, 
students are also able to: recognize and preserve culture; partners; appreciate the difference, and train social skills [4].

By combining interactive learning media and learning methods that support the learning of mathematics, it can be more fun and integrated mathematics learning and augmented reality-3D media. Where the whole learning process attempted to make the learners be themself. What the students learned to be a part of his personality, not only emphasized on the knowledge could have lost no imprint. As for the title of this paper is a "Victory of Culture Games (VOC-Games): Math-based Learning Media 3D and Augmented Reality as Cultural Preservation Efforts of Indonesia."

\section{METHOD}

The design of the VOC-Games based on three characteristics of technology education include (1) the systems approach, (2) orientation on learners, and (3) empowerment learning resources. So, VOC-Games designed with reference to the results of the analysis of the learning problems learners towards subjects of mathematics, then developed by optimizing all types of learning resources that are in accordance with the needs and characteristics learners. Of course, the VOC-Games also incorporate cultural preservation combined with integrated technology in the form of augmented reality so that it is able to integrate mathematics with culture.

\section{RESULT AND DISCUSSION}

\section{A. The design and Implementation of the VOC-Games As Cultural Preservation Effort through Mathematical Learning}

Augmented Reality works based on the detection of images called markers. The camera that has been calibrated will detect the marker that is given, then after recognizing and marking the marker pattern, the camera will calculate whether the marker matches the database it has [4]. If not, then the marker information will not be processed, but if appropriate the marker information will be used to render and display 3D objects or animations that have been made previously. The first stage of the VOC-Games games is making board for the games as depicted in Fig. 1.

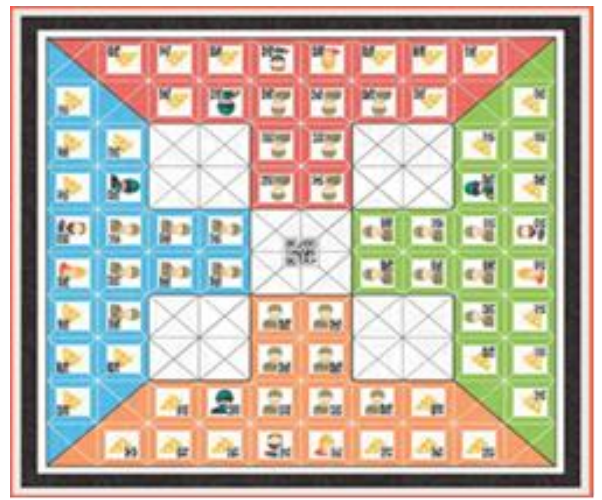

Fig. 1. Design of Board Games VOC

The next process is the creation of a 3D Hologram application Apps that support augmented reality. The user interface of the augmented reality can be seen in Fig. 2. For the next step, build the Box Projection Hologram 3D.

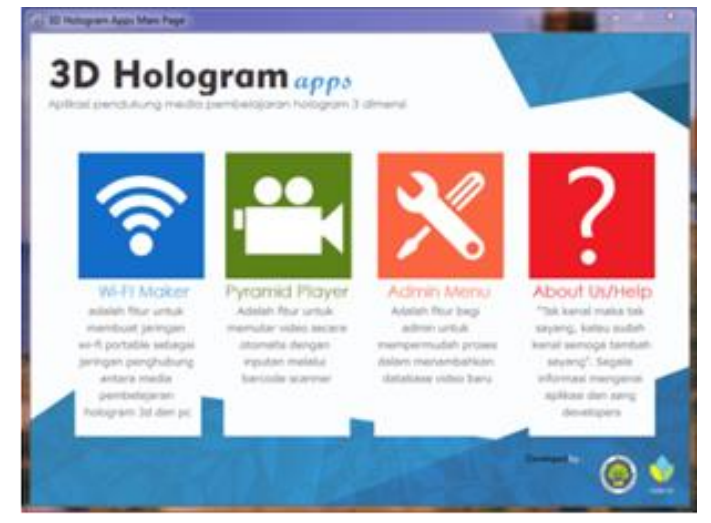

Fig. 2. User Interface 3D Hologram App.

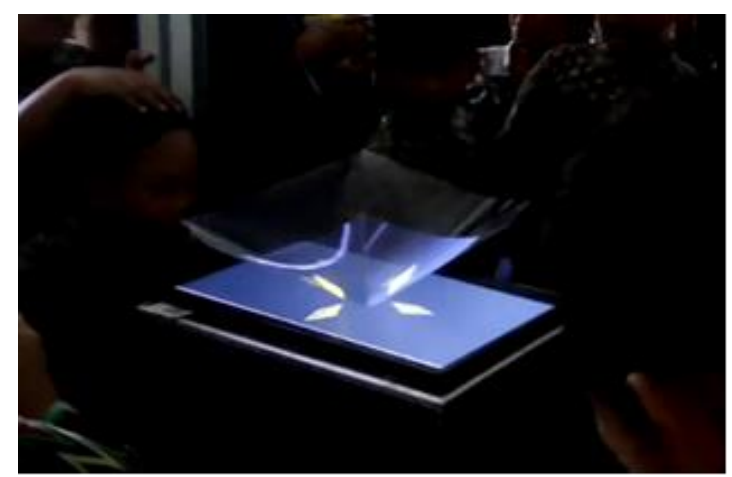

Fig. 3. Box hologram 3D

The 3D hologram box technology (Fig. 3.) works by projecting images in a layered plexi glass prism, allowing us to see virtual characters and content from different points of view. Combines 3D projection elements with an optical trick called "Pepper's Ghost," where objects inside are reflected on the glass panel. A projector in a box emits four images from the same object to the prism wall, forming one image so that it looks like a three-dimensional object. This technology is also used in developing 3D media based on augmented reality [9]. The next process for developing the media is making an audiovisual projection in the form of a math problem that is tailored to the design of the implementation study, and combine that with cultural elements. For the last step, do testing and repairing as needed.

Implementation or the flow of learning using media VOC-Learning Games include:

1) The entire team listen to a matter which is presented for one minute.

2) Students answer questions and when the answer is true then will get points in accordance with the type of hiding. As for the types of plots include -a swath of gold: the addition of the score 20-swath of warriors: the addition of the score 30-elite forces: the addition of a swath of score 40-King Swath \& Queen: Adding score 50.

3) If it does not get answered, students are allowed to ask for help from one of his team. But as a sanction, the team will be given a card to help with reduction of score 10 end games.

4) If a team no one can answer, then the question thrown to other teams. This will train the ability to observe, listen, and listen to the students. 
5) The team that successfully answering the question put his team's flag on a swath and get extra points. The team used the flag as a sign that the swath of property rights has become a team that can answer questions.

\section{B. Advantages of VOC-Games in Preserving Culture through Mathematics Learning}

Compared to mathematics learning media in general, VOC-Games has several advantages from:

1) Able to attract students' interest in learning.

2) Based on Augmented Reality.

3) Train students' abilities intrapersonal and interpersonal.

4) Emphasizing the internalization of character and cultural education values 8 actualized in the good treatment of students.

5) Easily realized and developed massively in Indonesia.

6) Content can be tailored to your needs, dynamic and attractive design.

7) Fun learning media can accommodate students from low achievers and high achievers.

It is designed to be able to train students and help in the dominant grouping in the class. Augmented Reality technology is a new breakthrough in learning media where the learning process in the world of education is still a lot conventional [4]. Conventional learning can lead to a level of saturation and lack of motivation of students in attending the lesson. Especially in mathematics subjects. Mathematics lessons are often considered difficult by students and difficult to understand.

Moreover, learning still uses conventional learning media. For this reason, the development of media learning mathematics programs by utilizing Augmented Reality (AR) learning media is needed to support students' mathematics learning [10]. Media developed using Android-based smartphone technology using integration between 3D and augmented reality. With the development of this learning media can be seen more real and can make these students become more interested in learning mathematics subjects [3].

\section{CONCLUSION}

VOC-Games connects the world of virtual/digital education with the real life of students. This can be done through problems that can be scanned by students on the game board. Through this concept, please be sure that the learning power and interest of students to learn mathematics will increase and will be stored in the long-term memory of students.

\section{ACKNOWLEDGMENT}

The author would like to thank to the Ministry of Research and Technology of Indonesia, especially for Director General of Higher Education who has provided PKM funding for this program.

\section{REFERENCES}

[1] Y.-H. Hsieh, L. Yi-Chun, and H.-T. Hou, "Exploring elementaryschool students' engagement patterns in a game-based learning environment," J. Educ. Technol. Soc., vol. 18, no. 2, p. 336, 2015.

[2] M. Dziallas and K. Blind, "Innovation indicators throughout the innovation process: An extensive literature analysis," Technovation, Jul. 2018 .

[3] J. Bacca, S. Baldiris, R. Fabregat, and S. Graf, "Augmented reality trends in education: a systematic review of research and applications," 2014

[4] M. Dunleavy and C. Dede, "Augmented reality teaching and learning," in Handbook of research on educational communications and technology, Springer, 2014, pp. 735-745.

[5] M. Hopkins, D. Ozimek, and T. M. Sweet, "Mathematics coaching and instructional reform: Individual and collective change," J. Math. Behav., vol. 46, pp. 215-230, Jun. 2017.

[6] J. Bobis, J. Way, J. Anderson, and A. J. Martin, "Challenging teacher beliefs about student engagement in mathematics," J. Math. Teach. Educ., vol. 19, no. 1, pp. 33-55, Feb. 2016.

[7] Sabri, "Berpikir Matematis untuk Pemahaman pada Tingkat Kesadaran." 2010.

[8] C. A. Maher, R. Sigley, P. Sullivan, and L. C. Wilkinson, "An international perspective on knowledge in teaching mathematics," $J$. Math. Behav., May 2018.

[9] W. Barfield, Fundamentals of wearable computers and augmented reality. CRC Press, 2015.

[10] M. Bano, D. Zowghi, M. Kearney, S. Schuck, and P. Aubusson, "Mobile learning for science and mathematics school education: A systematic review of empirical evidence," Comput. Educ., vol. 121, pp. 30-58, Jun. 2018. 